\title{
Urgent Media and Nontheatrical Ecologies
}

Jamaican Filmmaker Esther Figueroa in Conversation

\begin{abstract}
This introductory essay and interview trace Esther Figueroa's career in media, particularly the films she has written, directed, edited, and produced as part of specific campaigns to mobilize Jamaica's environmental movement against bauxite mining, tourism, and overfishing. Figueroa discusses her upbringing, her work in television in Hawaii, and the roles that feminism and race have played in her life and work. KEYWORDS climate change, documentary, Esther Figueroa, Jamaica, nontheatrical
\end{abstract}

"The first step towards reimagining a world gone terribly wrong would be to stop the annihilation of those who have a different imagination-an imagination that is outside of capitalism as well as communism. An imagination which has an altogether different understanding of what constitutes happiness and fulfilment. To gain this philosophical space, it is necessary to concede some physical space for survival of those who may look like the keepers of our past but who may really be the guides to our future. To do this we have to ask our rulers: Can you leave the water in the rivers, the trees in the forest? Can you leave the bauxite in the mountain?"

-Arundhati Roy, “The Trickledown Revolution,” 20 io

What does the rubric of environmentalism and film mean in Jamaica, a Caribbean island whose cultural influence extends around the world through reggae music and Rastafarianism? What does it mean to look at the world through a micro-focus on a small space and its specific environmental issues? Esther Figueroa's video making embodies the themes and paradoxes that inhere to this question. Eschewing abstract theory and the norms of indie film style, Figueroa's didactic narrative approach aims to illuminate how human actions in various parts of the world, particularly the overconsuming Global North, have brought us to our current moment of unequally shared crisis. Following

Feminist Media Histories, Vol. 6, Number 2, pps. I20-147. electronic ISSN 2373-7492. (C) 2020 by the Regents of the University of California. All rights reserved. Please direct all requests for permission to photocopy or reproduce article content through the University of California Press's Reprints and Permissions web page, http://www.ucpress.edu/journals.php?p=reprints. DOI: https://doi.org/I0.1525/fmh.2020.6.2.120. 


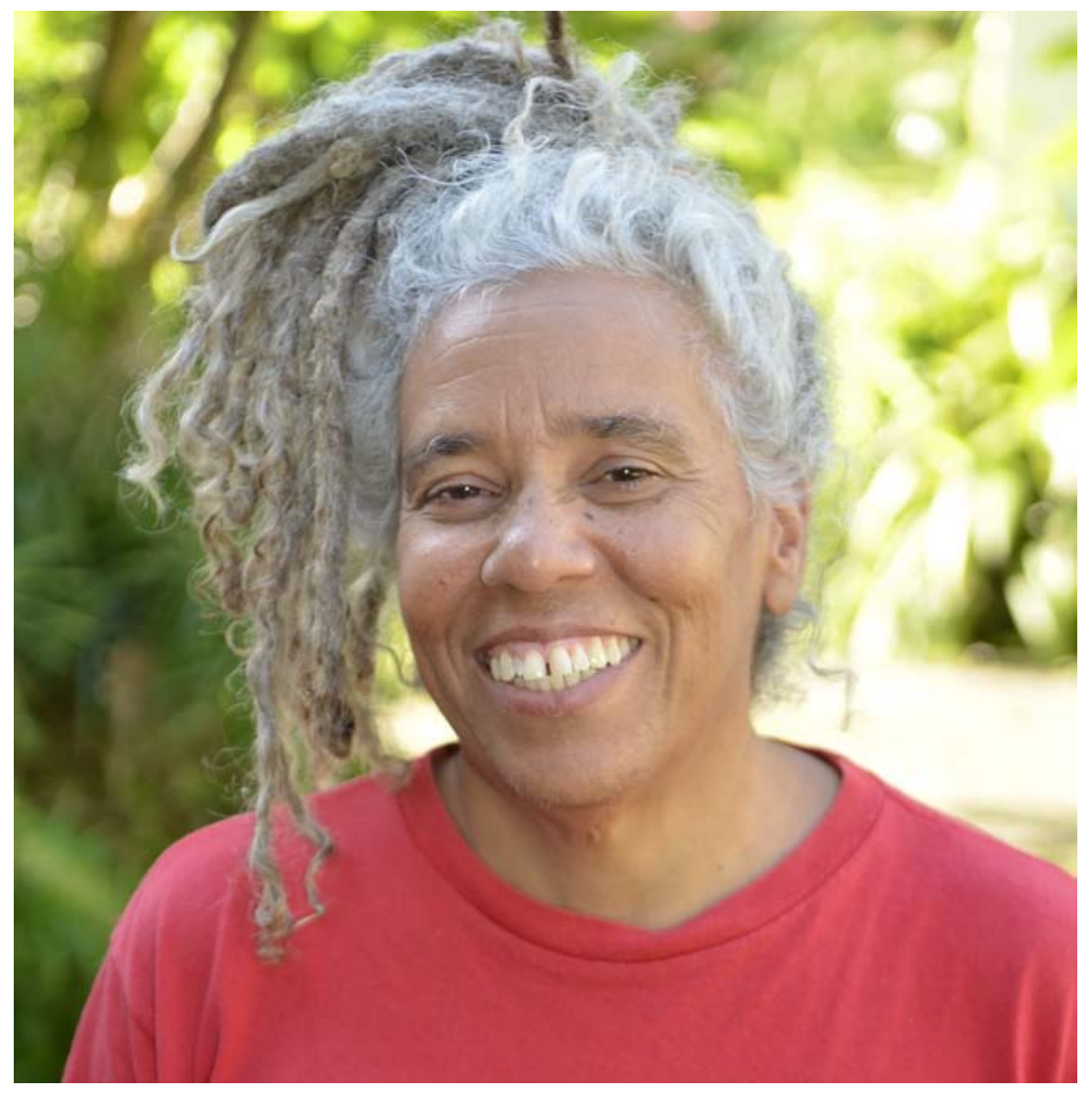

FIGURE 1. Esther Figueroa, a feminist filmmaker working on behalf of the environmental movement in Jamaica. Photo: Mary-Angela Fatta, courtesy the filmmaker.

this introductory essay is a rare extended conversation with the Jamaican feminist filmmaker (fig. I) about her pedagogical concerns and what I call her aesthetics of urgency.

Figueroa's work is a prime example of "useful cinema," a term developed by Charles R. Acland and Haidee Wasson to think through the ways that organizations and agents of organizations use the media to advance their goals and connect with audiences. As they put it, "useful cinema" denotes "a body of films and technologies that perform tasks and serve as instruments in an ongoing struggle for aesthetic, social, and political capital." Defined in this way, the concept "does not so much name a mode of production, a genre, or an exhibition venue as it identifies a disposition, an outlook, and an approach toward a 
medium on the part of institutions and institutional agents." But there is an urgency to Figueroa's work because it is incited by specific campaigns involving environmental crises, as she explains in the interview.

As the effects of climate change become more broadly felt in the Global North, Figueroa's aesthetics and information will become ever more brutally relevant. But that future film theory is now. As University of the West Indies physicist Michael Taylor described the current conditions in The Guardian, "By the end of the current century, the Caribbean region will warm a further ${ }_{2-3} \mathrm{C}[3.6-5.4 \mathrm{~F}]$ over the $\mathrm{I} \mathrm{C}[\mathrm{I} .8 \mathrm{~F}]$ already seen in the last century. We project annual rainfall amounts will decrease by up to $40 \%$, posing a significant challenge to already water stressed islands. Projections also show sea levels rising by $\mathrm{I}-2$ meters $[3-6$ feet], far exceeding the rise already recorded." $\mathrm{A}$ Jamaican independent filmmaker like Figueroa challenges the dominance of the Global North and its biases in film studies, independent filmmaking, and environmentalism by shifting the conversation out of the United States and Europe and to the Caribbean, where the effects of climate change are already being keenly felt -in the form of catastrophic storms, more frequent and heavier rains, and fewer and hotter dry days—and rigorously discussed.

Three main environmental problems animate Figueroa's video making: tourism, overfishing, and bauxite mining. Her pragmatic approach centers the interdependency of people and their physical environment as well as the interconnections of seemingly very different people in seemingly disparate and unrelated places. Her videos, especially the shorter educational and message-oriented work that she has made to serve specific community-driven campaigns, are aimed initially at mobilizing viewers in Jamaica. Although the videos can be quite lyrical at times, they are less about visual uniqueness and more about an informed, necessarily polemical political consciousness expressive of how what happens in the postcolonial moment links back to what happened in colonial history. A sense of awe, a hallmark of naturalist and environmental films that feature soaring music and wide aerial and panning landscape shots, is largely absent save for establishing shots. Figueroa's videos bring viewers close, and, particularly in the features, the narrative accumulates through argumentation and the compilation of historical fragments mined from archival news footage, industrial films, and promotional material dating from the 1950s and 1960s, which she places in dialogue with interviews she conducts with today's farmers, activists, scientists, artists, and politicians.

This interview adds to the scant scholarship on Figueroa's films and the history of nonfiction filmmaking in Jamaica. "Unbinding Identities" (20I4) by 


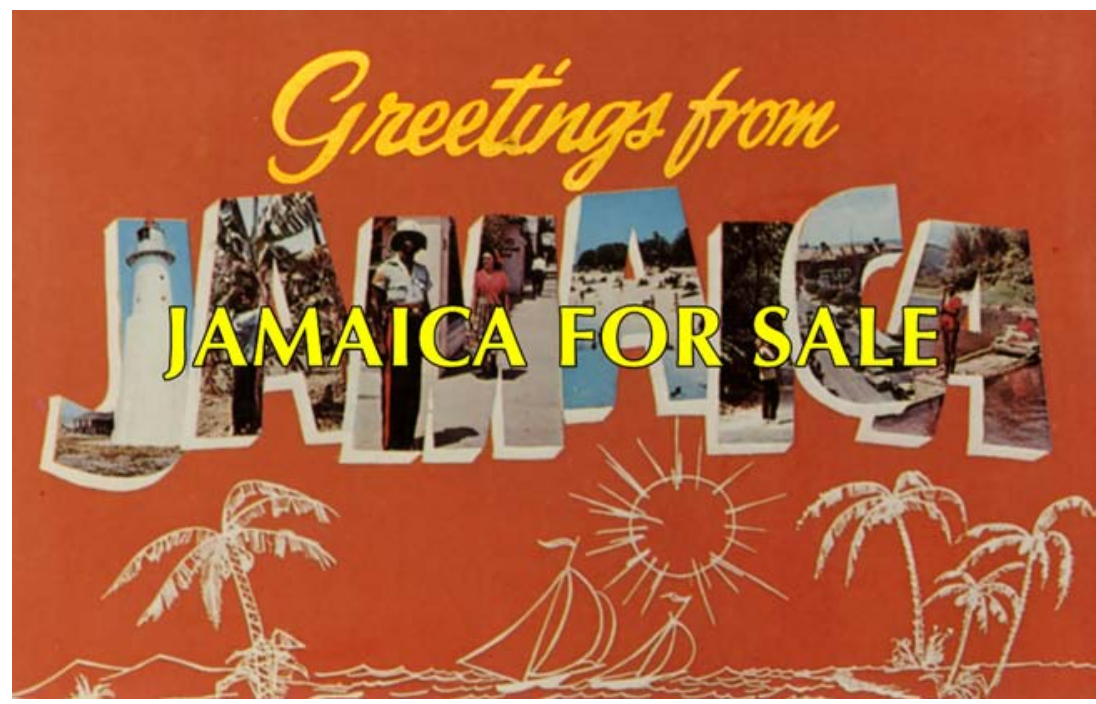

FIGURE 2. Promotional poster for Jamaica for Sale (dir. Esther Figueroa), 2008. Courtesy the filmmaker.

Rachel Mosley-Wood focuses on Jamaica for Sale (2008, fig. 2), attending to how this documentary "critiques the construction of a national identity founded on the promise of wealth from tourism." Keith Warner's On Location: Cinema and Film in the Anglophone Caribbean (2000) provides context for a range of filmmaking in the region, but its publication predates Figueroa's work. ${ }^{6}$ Jamaica does have significant nonfiction film media through both government sponsorship and non-Jamaican explorations financed abroad. In the pre-independence era of the I950s, Martin Rennalls led the Jamaica Film Unit, part of the Education Department, which aimed to educate the public on issues such as farming and dairying techniques as well as social issues such as the medical treatment of syphilis. ${ }^{7}$ In the 1960 , Franklyn St. Juste's short $16 \mathrm{~mm}$ films Festival '68 (1968) and Water Is Life (ca. 1964), made for the Film Unit, stand out as poetic treatments of would-be prosaic material. St. Juste went on to serve as cinematographer of the acclaimed postcolonial film The Harder They Come (1973). Meanwhile, non-Jamaicans have generated significant and internationally known nonfiction films set in Jamaica. Among these are Alan Greenberg's Land of Look Behind (1982) and Stephanie Black's films $\mathrm{H}_{2}$ Worker (1991) and Life and Debt (2003). While few Jamaican films can be considered nature films, the Jamaican landscape, particularly its beaches and waterfalls, serves as a backdrop to narratives informed by tourism in Dickie Jobson's 
Countryman (1982) and Kevin Rodney Sullivan's How Stella Got Her Groove Back (1998).

Most of Figueroa's works are short, thirty minutes or less, and center on a specific problem for a specific area and group of people. In Massa God Fish Can Done (2009), Cockpit Country Is Our Home (2012), and Cockpit Country: Voices from Jamaica's Heart (2007) Figueroa uses a straightforward expository narrative structure where science is personalized and global environmental problems are framed in terms of community activism. Cockpit Country Is Our Home begins with a first-person voice saying "I am Cockpit Country," as though speaking from and for the distinctive hills that characterize the region and are shown on the screen. Significantly, Figueroa uses a woman's voice, giving the impression that Mother Earth speaks. Rather than passively looking or photographing for a sense of vastness, something beyond the human, Figueroa does just the opposite: she embodies the land as a speaking woman who describes her history and attributes. In effect, Cockpit Country introduces herself to the audience (fig. 3). She seeks to connect with her viewers and teach them to connect and befriend nature rather than, or in addition to, revering and/or fearing it.

The visual forms of Figueroa's feature films Jamaica for Sale and Fly Me to the Moon (2019) are different in tone and approach from the short activist

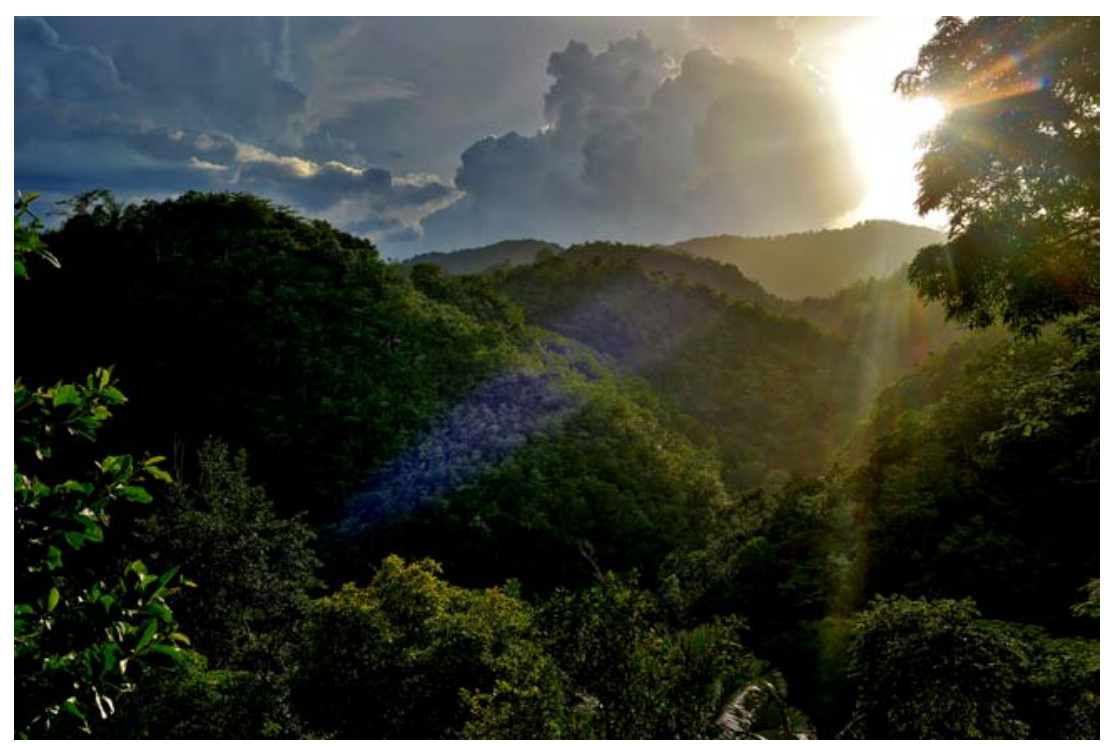

figure 3. Cockpit Country, Jamaica. Photo: Ted Lee Eubanks, courtesy the artist. 
videos. They rather resemble experimental found-footage films such as Bruce Conner's A MOVIE (1958), with its humorous juxtapositions, or the recycling of rescued film fragments in Bill Morrison's Decasia (2002). They are, in this sense, elegiac, but their ethos of recycling revives the fragments into new narratives. Figueroa's work mourns lost landscapes in that many of the places the videos document have changed radically, if they are not already now gone. At the same time, her work uncovers the ideological intentions that were just below the surface of the industrial films and other propaganda she mines. Figueroa's documentaries are about real life-food systems, air quality, land, belonging, survival, history-and likewise the following interview touches on essential elements of life and community, as it documents in her own words a feminist filmmaker's life growing up in twentieth-century Jamaica. From the interview, it becomes clear that Figueroa's concept of feminism, informed by reading "radical feminist propaganda" as a young woman, is deeply experiential and immediate, rather than theoretical. As she explains, she foregrounds the voices, roles, and experiences of women but is skeptical of being placed in a category of women's filmmaking.

Jamaica for Sale critiques the conventional wisdom that tourism is the "savior" of developing countries. One especially remarkable sequence begins with the inviting sounds of the ocean before cutting to a powerful juxtaposition in which an instrumental rendition of the Jamaican national anthem, "Jamaica, Land We Love," plays over images of active construction (here rendered as destruction, clearly) sites along the coastline, punctuated by the arrival of a large tourist bus. The video further sheds light on the environmental consequences of Jamaica's dependency on tourism as well as its impacts on the employees and communities who supposedly benefit from this holiday economy. The film contains essential information about the hotel industry, for instance the low wages paid to both construction workers and hotel employees, and about the protective role of mangroves-essential buffers that are routinely destroyed to make way for new hotels and idyllic beaches.

Fly Me to the Moon also features local Jamaican politics and calls for greater accountability among the so-called stakeholders operating in Jamaica's interior in locations such as the biodiverse Cockpit Country. It focuses on the specific mining companies and government officials who facilitate leases that permit mining. Fly Me to the Moon is epic in scale, linking the struggles in a small town in Jamaica to those in India and other parts of Asia. The two-hour video explains that bauxite - the ore used for the production of aluminum, that flexible, lightweight material used in soda cans and space shuttles-comes from small, 
mostly unknown towns in Jamaica, seemingly a world away from the space industry. Figueroa detailed the significance of bauxite mining in her July 28, 2019, editorial in Jamaica's national newspaper The Gleaner, published on the fiftieth anniversary of the moon landing:

The Apollo in capsule was primarily constructed of aluminum which is made from bauxite, the rich red soil strip mined and shipped out of South America and the Caribbean for over 100 years. Jamaica was the world's largest producer of bauxite when Apollo in landed on the moon. By 1969 , the powerful multinational aluminum companies in Jamaica had accumulated huge amounts of land, and tens of thousands of rural Jamaicans were displaced, resettling in expanding urban centers like Brown's Town, Mandeville and Kingston or migrating to the UK and North America. ${ }^{8}$

The visual content of Fly Me to the Moon includes footage of the Apollo II voyage, promotional materials used by bauxite companies, commercials for aluminum products, and other historical media. The video is itself a historical repository. Its archival images are placed in dialogue with current interviews and documentary evidence showing the fallow, un-farmable condition of the land that has been mined by companies such as Noranda Bauxite Limited and Jisco Alpart. In using footage of past and current Jamaican and US politicians, Figueroa demonstrates the continuities across the policies of the 1960s, 1970s, I980s, and I990s up to today and underlines the avarice and arrogance that drove them in both nations.

Access to Figueroa's work has been relatively limited. As opposed to such high-production nature documentaries as BBC's Earth (2015) or Netflix's Our Planet (2019), Chasing Coral (2017), and Chasing Ice (2012), which had far bigger budgets than Figueroa ever does and are streaming and promoted for general audiences on popular platforms, her feature documentaries and short videos are not typically promoted with a theatrical release for the general public, nor have they been distributed at festivals for the most part. ${ }^{9}$ They have been screened within educational and environmental circles for many years in Jamaica, but they are not yet world cinema products. Figueroa has uploaded her work to YouTube, where it is theoretically available to anyone, yet, perhaps because the videos want for necessary framing, they remain effectively inaccessible in many ways, particularly to viewers outside Jamaica who likely will not have heard of her. ${ }^{10}$ The "network connections" required relate to intellectual framing as well as internet access. The body of work is right there, free to view, for all to see, yet at the same time lack of promotion and press coverage creates a kind of invisibility, and 
YouTube is itself an often idealized yet unstable and imperfect archive whose digital infrastructure and future availability are not guaranteed.

In Jamaica, Figueroa's work fits into an "experiential learning" framework that "involves communicating with farmers in a manner that encourages learning, participation and partnership." ${ }^{\text {II }}$ Her video making works as a forum in Jamaica where people can talk about how they understand the currents of climate change as they work to detangle "the tentacles of history," to borrow a phrase from Figueroa's 2014 novel Limbo. ${ }^{12}$ In the videos, Jamaican farmers, shopkeepers, and those who understand and have breathed the true consequences of human (in)action around land use and water and air quality push back against the colonial past and the neocolonial present. The colonial legacy, though not always explicitly referenced, is a central target of environmental work in Jamaica. As artist Deborah Anzinger writes in Caribbean Quarterly: "The physical structure of the world, our place within it, and the stories we create through it indicate residual syntactical treatments of space (space as in the land, and space as in raced and gendered bodies) that colonialism and empire have left on culture; thereby shaping our person-to-person and person-tonature relationships." "'3 "Colonial syntax" refers to obstacles in patterns of thought about the land that need to be undone. In her novel Figueroa further explicates the colonial paradigm: "Whatever tropical plants some Englishman like [Flora's] grandfather once thought were pretty, so we now think are pretty." ${ }^{\prime 4}$ Every decision about buildings, trees, and blades of grass seems to bear witness to the traumatic and unfinished past. Thus visual environmental efforts in Jamaica involve decolonizing work, questioning what was thought to be useful, what was thought to be beautiful, interrogating the very meanings of progress and wealth.

A series of editorials by professor emeritus of culture Carolyn Cooper has recently brought attention to the lack of beach access for Jamaican locals; one story was published with the headline "Emancipate All Beaches Now!" In it, Cooper argues that "Emancipation Day [August I] is a prime occasion for us to reflect on the legacies of plantation slavery."' The University of West Indies Professor has been quoted in the international press as suggesting that beaches in Jamaica are still regulated in ways that presume that locals have no land rights, no right to expect leisure at the beach. She told Reuters, "That's just the legacy of our history. The majority of the society wasn't expected to enjoy the benefits of the society." ${ }^{\text {"I }}$ Posting to Facebook from St. Vincent and the Grenadines, visual artist Nadia Huggins referenced her ocean photography and captioned an image of a plastic cup floating underwater (fig. 4): 


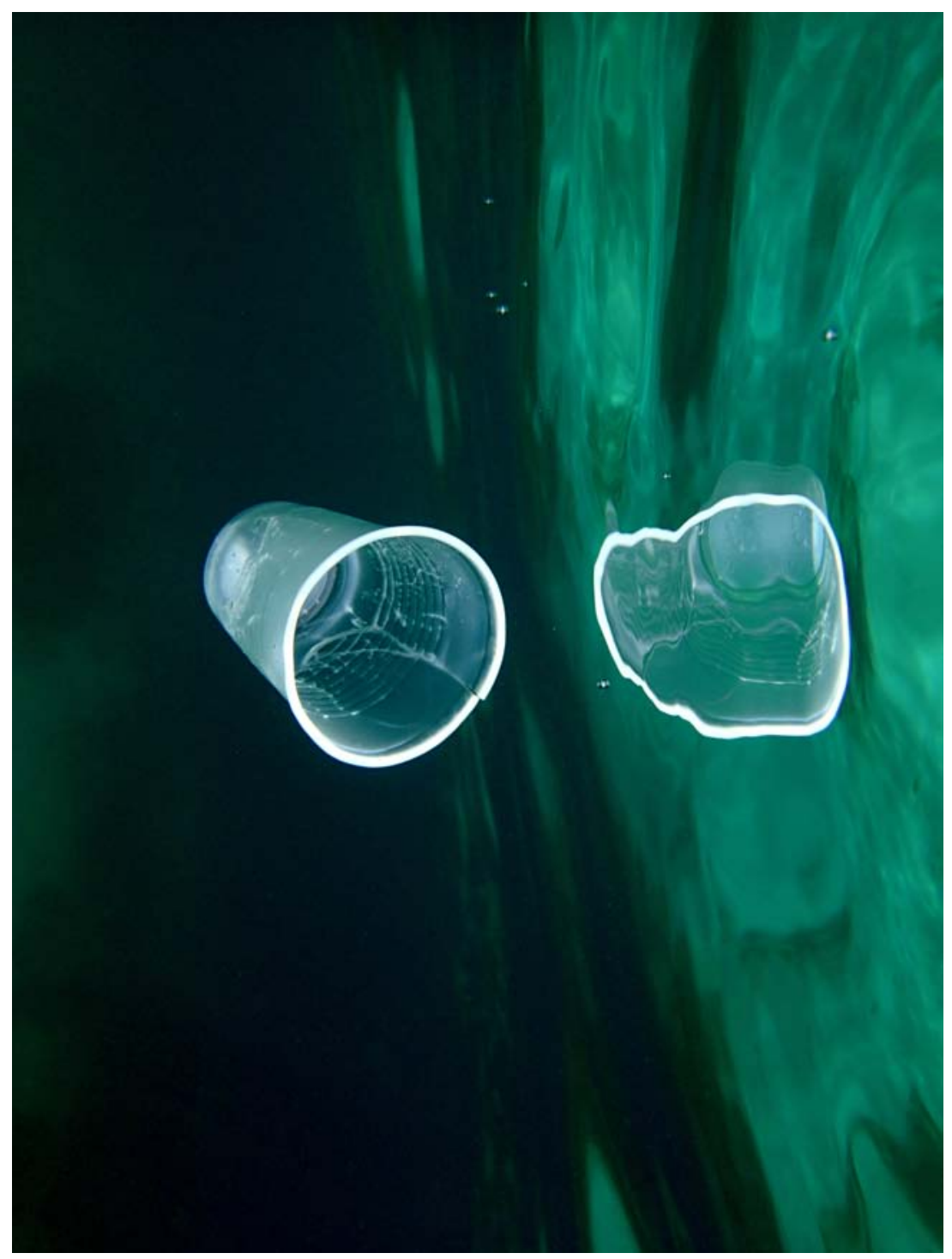

FIGURE 4. Plastic container photographed under water. Photo: Nadia Huggins, courtesy the artist.

Do you know how frustrating it is to see this every single time I swim?? Outside each frame, of every single underwater image I shoot, there is marine debris which I intentionally leave out. From plastic cups, bottles, fishing lines, condom wrappers, plastic forks, the list goes on. Just a reminder that the oceans are a mess and it's our fault. ${ }^{17}$ 
Initiatives taking place in Jamaica include anti-littering campaigns, beach cleanups, and a ban on plastic bags such as those used for grocery shopping, but overcoming the colonial mental habit of exploiting the land is also targeted. ${ }^{18}$

That this interview and Figueroa's early public screening of Fly Me to the Moon and other works in the United States took place in Bloomington, home to several superfund sites, is significant. The place has more in common with Jamaica than might at first be apparent. Indiana University is celebrated, especially among its own, for having one of the country's most beautiful college campuses. ${ }^{19}$ Like Jamaica, both the campus and Bloomington's physical attributes are idealized for consumers inside and outside the area. Lauded as wonderful for students, for faculty with young families, as well as for retirees, the town of roughly eighty-five thousand residents, forty thousand of whom are students, lies within just a few miles of three superfund sites: Neal's Landfill, Bennett Stone Quarry, and Lemon Lane Landfill. ${ }^{20}$ Bennett Stone Quarry, similar to the Sanders Quarry (now filled in) and which was made famous in the film Breaking Away (1979), is left over from Indiana's limestone mining industry. Because of actor Dennis Quaid's iconic swim scenes in the Best Picturenominated film, it is easy to imagine a former quarry full of refreshing blue water, but Bennett is in fact a four-acre pit full of "demolition debris, household wastes and electrical parts" where cleanup is ongoing. ${ }^{21}$ The Lemon Lane Landfill, "which had no bottom liner or runoff controls," took in municipal waste from 1933 to the mid-1950s. ${ }^{22}$ PCBs were reportedly released into sediment and groundwater when "metal scavengers broke open the capacitors to reclaim internal metal capacitor parts" and the effects have been long-lasting and continue today. Likewise, PCBs have leaked into groundwater through Neal's. ${ }^{23}$

All of this is to say that wherever we are, we are never far from serious environmental problems. Wherever we live, no matter how beautifully it might be landscaped, we are already ourselves suffering, albeit in unequal and distinct ways, the shared fate of the lasting deleterious effects that extractive industries and ignorant environmental policies have left behind in our own backyards. ${ }^{24}$

On March 24, 2019, Figueroa screened an in-progress version of her film Fly Me to the Moon at the Indiana University Cinema, sponsored by the Black Film Center/Archive, where I am director, as part of the series "Black Sun/White Moon," which I curated and which was cosponsored by the university's Creative Collaborations program and the Center for Latin American and Caribbean Studies. Figueroa also screened Jamaica for Sale along with shorter works in a series called "Nontheatrical Ecologies" at the IU Libraries Moving Image Archive Screening Room on March 25, 2019. This interview is adapted 


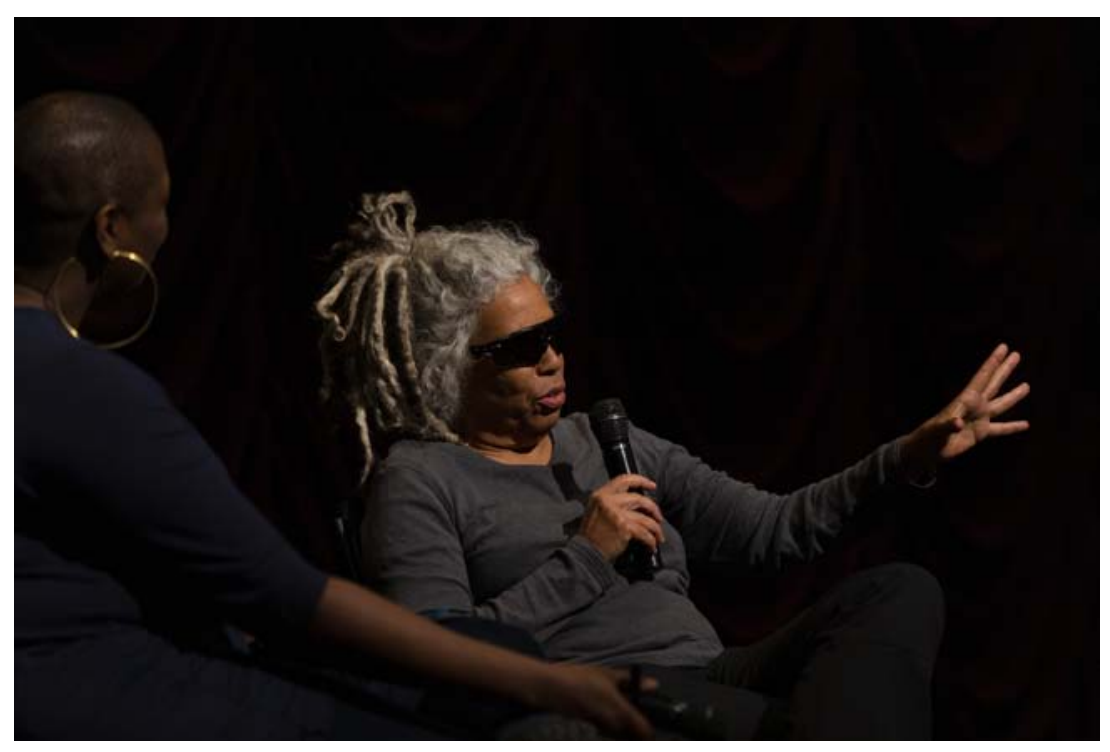

FIGURE 5. Esther Figueroa discusses her career with the author at Indiana University Cinema in Bloomington, March 24, 2019. Photo: Chaz Mottinger, courtesy Indiana University Communications.

from a recorded conversation that took place during that same visit on March 24, 2019, in Studio 8 at Franklin Hall in Bloomington (fig. 5). We began at the beginning.

ESTHER FIGUEROA: I had a very lucky and privileged upbringing. I grew up primarily at the University of the West Indies at Mona in Jamaica, where my father, John Figueroa, was a professor of education. He was also a poet and a journalist and a famous cricket commentator. Derek Walcott was his student and his mentee. ${ }^{25}$ I grew up among so many interesting people, not just from the West Indies but across the world, who are involved with the arts, the sciences. A wide range of intellectuals. In addition, I was in the United States for two years. I was actually in Bloomington, Indiana! This is my first return to Bloomington since I was seven. I was here from 1965 to 1966.

TERRI FRANCIS: How was that experience for you?

EF: Well, childhood-wise it was fairly traumatic and not very pleasant.

TF: What happened?

EF: Basically, it's where I discovered I was a nigger. And I was a child. It was very traumatic and strange. When I was in Bloomington, I was very good at 
sports. I've always been an athlete and I played baseball and ran track. I was the fastest in my class, I think. I went to Rogers Elementary and I remember hearing something about "the nigger can run," you know? In England I was the wog, which means nonwhite, and in Jamaica I was pook, which means pork, which is a derogatory term for a white person. So, when you want to talk about race, I can talk about race.

TF: We'll get there. When you returned to Jamaica, did you stay through high school?

EF: I started off in what we call prep school in Jamaica. I attended Saints Peter and Paul, which was a new Catholic school at the time. I come from a very Catholic family. We have three generations of nuns: my sister, two aunts, and two great-aunts. Then I came to the US system. Then I went back to Jamaica. I continued in prep school and then the beginning of high school. Then at age thirteen we moved to Puerto Rico and I changed school systems again, back to the US system.

TF: And were you changing languages?

EF: Yes. I finished school when I was fifteen and fled Puerto Rico when I was seventeen to attend the University of Miami for two years because my ambition was to be a tennis professional. Unfortunately, at that time, Puerto Rico had a gender role situation where girls did not do sports, so that really screwed up my tennis ambitions. I went to the University of Miami for two years and it was clear I wasn't going to make the tennis team there, so I transferred to George Washington University, and I was on the tennis team there. I was a walk-on. So, the chronology is that when I was thirteen, we moved to Puerto Rico. That was 1971. I left in 1975 and went to Florida for two years, and then I moved to DC in 1977.

TF: Tell me about majoring in history.

EF: Coming from an academic background, you have certain notions as to what one should study. At the University of Miami, I thought I would study communications. I didn't know what it was, and I ended up going to a survey course in this big lecture hall with TVs, and there was this guy who said he was a member of the Academy. That's all I remember about him. He kept talking about the Academy and was just basically gossiping about Hollywood. We were watching canonical films. At that time, the University of Miami was called Suntan U. Although I think it's improved from when I was there in the I970s. I had this notion of how your parents sacrifice, how hard it is to be in these sorts of places. I could never understand 
the American attitude that college was a place for fun and drunkenness and acting out. To me it was bizarre, frivolous, and this course was frivolous, and I thought, well, if this is communications then it's nonsense and I need to do something serious. When I transferred to George Washington, I took history and languages because that seemed serious.

TF: Did you watch movies and television growing up?

EF: I grew up among writers. I learned to read by the time I was three or four and I was writing little silly stories and stuff at a young age. We didn't have television when I was growing up. It didn't exist in Jamaica, and when it came in, my father wouldn't allow it in the house. We'd go see stupid movies, like The Sound of Music (1965). I think we saw James Bond and the like, but not often. So my references were never cinematic or from television at all. They were literary, or artistic. For instance the performing arts. Radio was a huge thing in Jamaica. We used to listen to radio dramas from far away as well as local ones-people would stop everything and listen, radio was so huge. My dad had a shortwave radio that brought in broadcasts from all over the world. So, it was radio, it was literature, it was the visual and performing arts. Television, no. Films, no. Now, very late in life, I am coming to film. The films I watch are primarily from Spain and Latin America and other parts of the world. I hardly watch any US film at all.

TF: Tell me about your move to the University of Hawaii. How did that come about?

EF: When I was in DC in the I970s, I had a Hawaiian girlfriend, and she wanted to go home.

TF: Love and travel.

EF: If I was going to stay in America, I had to be in school.

TF: The visa, the visa.

EF: Sure, but also, why not Hawaii? It was the furthest, most un-American place you could possibly be, and islands at that.

TF: Did it feel like Jamaica, or was it quite different?

EF: It's similar and different, in that there are lots of similarities that are sort of tragic.

TF: Like what? 
EF: Well, the occupation of Hawaii. It's called a state, but it's basically a colonial occupation. We went through that in Jamaica for five hundred years. The genocide of the native Hawaiian people is much more recent than the genocide of the Taino in Jamaica or the genocide of the Africans who were trafficked to Jamaica. When you come from a colonized place and you're very aware of that history and you go to a place where it's happening in the here and now, in a way that's still happening in the here and now in Jamaica, but removed in a slightly different way, you see it and feel it quite strongly, in a way that many people experiencing it don't have that context and that political analysis. That's actually how I got involved in being a filmmaker in Hawaii.

My partner at the time, Heather Haunani Giugni, who is a native Hawaiian, was working in the news department at KGMB, which was a CBS affiliate, and it was extremely sexist. ${ }^{26}$ She wanted to be a director, but they wouldn't train women to be directors. She, along with an entire generation of Hawaiians, were becoming conscious about Hawaiian identity, trying to reclaim Hawaiian language, Hawaiian practices. The Hawaiian language had been banned. Children had been beaten for speaking it. The land had been taken, and 80 percent of the population had died during contact. So there was trauma. There was this entire movement that wasn't just a renaissance of Hawaiian culture and knowledge and trying to reclaim and return, but also a fight for sovereignty and rights and separation and independence, an acknowledgment of what was going on in this place. And here we have similarities with Jamaica as a tourism paradise. I graduated in 1984 and I had this consciousness of coming from a colonized place. I had the political consciousness, but I also had the critique of television and media. In the broadcast media, there was no local representation, no native Hawaiian presence whatsoever, except as a touristic, exoticized, or absent presence.

We started the first Hawaiian television series that was on commercial and public television, and we chose-I chose-the name Enduring Pride. ${ }^{27}$ But I realized later that the notion of pride, ha'beo, was not part of the Hawaiian discourse. Instead, it comes straight out of civil rights and gay rights. That was not a discourse that Hawaiians themselves were using. So, in a sense, I was kind of imposing a concept that wasn't really there, but they found a translation for it.

E Mau Ana $\mathrm{Ka} \mathrm{Ha}$ 'aheo was a magazine show that covered everything from language to dance, history, contemporary issues. Most of the content we produced was attempting to perpetuate Indigenous cultures and knowledge and having a local presence. I came into filmmaking as an Indigenous practitioner, 
though I'm not Indigenous. That was the approach. It was Indigenous filmmaking, which is about not just representation, but changing or having alternative forms, narrative forms, discursive forms. If what we call haole, the white way, of doing things is very fast and very whatever-whatever, the Indigenous way isn't. They don't mind someone talking for an hour or two hours or three hours. You will sit. So the type of storytelling, whether it's linear or nonlinear, how long, how slow, how fast-came out of those principles. It's interesting because when you introduced my films at IU Cinema, you described my work as oral history. That's indeed how it started. It started literally as oral history and also documenting practices for which there were either very few practitioners left alive or very few people who were trying to pass on this knowledge.

TF: Was this broadcast on the CBS affiliate?

EF: The majority of our shows were on either the public station or the commercial affiliates. They were in film festivals, and in the schools. They were used as community projects.

TF: At what point do you go back to Jamaica?

EF: I was going back and forth, but I moved home permanently in 2006.

TF: Ah, so there was quite a bit of time where you were either back and forth or based in Hawaii.

EF: I was twenty-five years in Hawaii, minus the time I was in DC getting my $\mathrm{PhD}$.

TF: Tell me about returning to Jamaica. What brought that on?

EF: Initially, in my relationship with Heather, we were supposed to be half time in Hawaii, half time in Jamaica, but that never happened. I was in Hawaii all the time and it seemed people thought I was Hawaiian. It was great. It was like being at home, but at the same time in a parallel reality. I think one lives many lives at the same time, and you kind of go in and out of them depending on where you are. Ultimately I wanted to resume my interrupted life, my life at home in Jamaica. When we had moved to Puerto Rico when I was thirteen, I got interrupted.

TF: What do you mean?

EF: In Jamaica, I had family. Though my parents lived in England (they passed twenty years ago), in Jamaica I had family, and elsewhere I had friends, but I 
never had the two in the same place. The Hawaiians have a wonderful word, kuleana, that's very, very, very hard to translate, but it means What is your responsibility? What are you supposed to do on this earth? What have the ancestors placed you on this earth for? I would always go back to Jamaica and I would think, well, when I come back, what should I do? I decided that I'd come back, and when I did, the environment would be my emphasis and my responsibility, my kuleana.

TF: Was the Jamaica Environment Trust already in existence when you arrived?

EF: Absolutely. Yes.

TF: How did you get involved with that?

EF: Every time I'd go back to Jamaica, I'd have meetings with different people. A friend of mine was head of the Nature Conservancy in Hawaii, and she told me about the nature-conserving Jamaicans and said I should meet with them. I had a meeting with Diana McCaulay and Jamaica Environment Trust. I said, "I'm back in Jamaica. I'm a filmmaker. I'm proposing to make environmental media for free for the environmental movement." She said, "I can keep you in business for the rest of your life."

I thought that we would set up another meeting and do the usual institutional thing where you plan short term, medium term, long term, and come up with a strategy of different kinds of products that you need to produce. But it turned out that there was an emergency, and that emergency was bauxite mining in Cockpit Country (figs. 6, 7). People had discovered that a lease had been given for mining there. There had been efforts for decades to organize around Cockpit Country, trying to protect it, but this was a crisis. An entity called the Cockpit Country Stakeholders had been formed. Early in 2006 we went into Cockpit Country and I shot for maybe two and a half or three days, and turned that into Cockpit Country: Voices from Jamaica's Heart. That was the first.

TF: In Jamaica, did you approach your media practice through what you had learned in Hawaii?

EF: Absolutely, and it's not just media practice. It's the knowledge that I gained about the relationship of human beings to the world. The Indigenous perspective is a very different perspective, where the place of the human being is not central. The place of the human being is part of the environment, and it's a reciprocal, mutual thing. You're not here to take and take and take and take. It's ways of thinking about the place of the human in the cosmos and in 


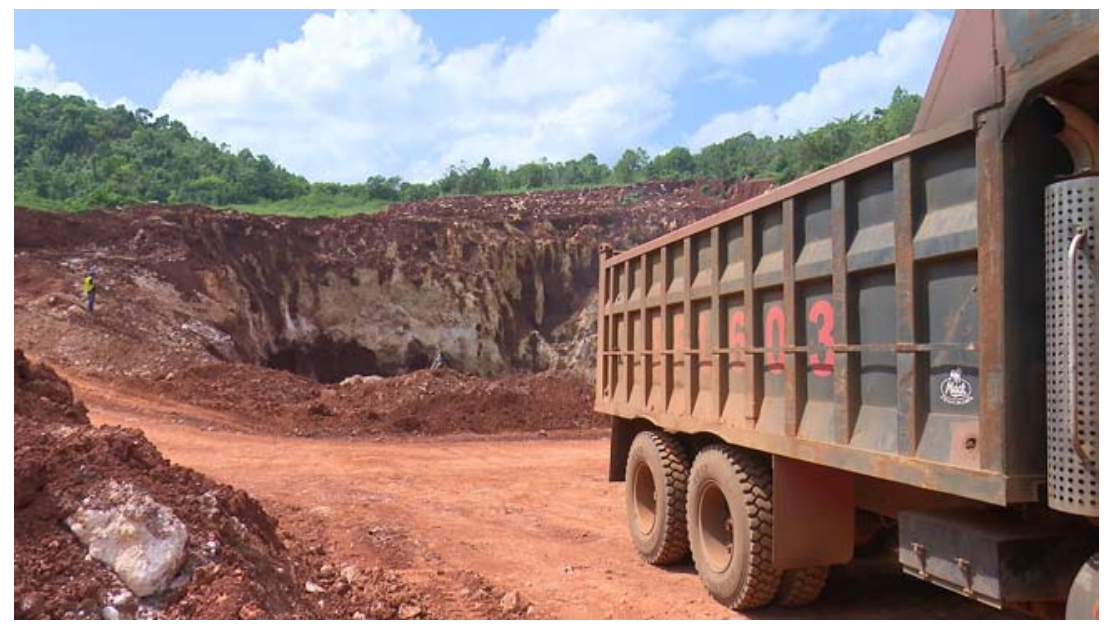

FIGURE 6. Bauxite mining displaces residents and renders soil unsuitable for farming. Photo: courtesy the filmmaker.

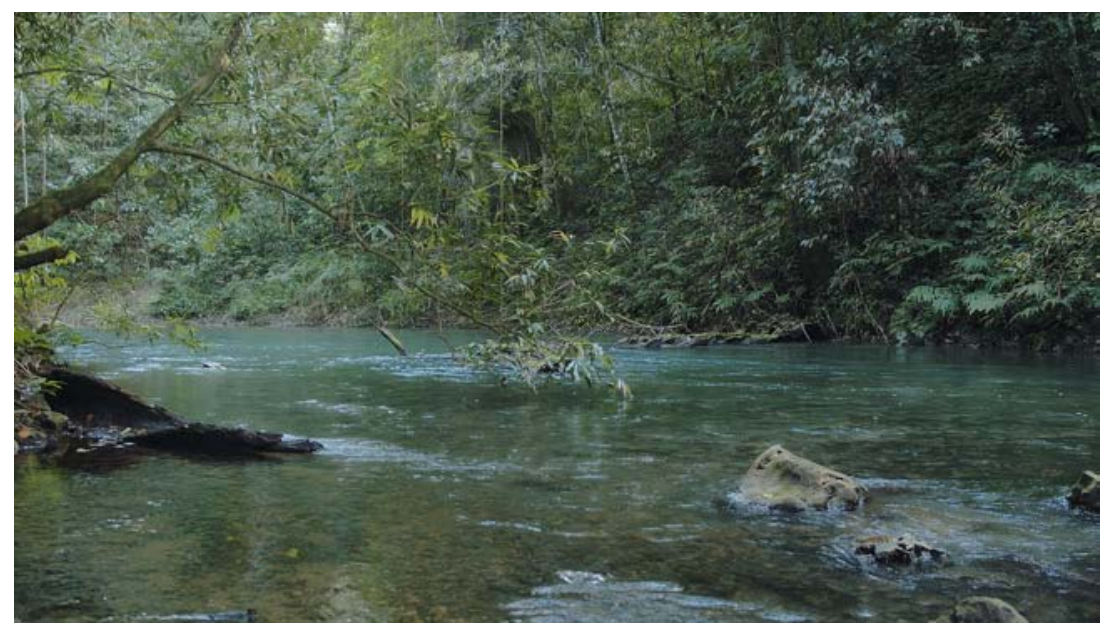

FIGURE 7. A symbol of resistance where the Maroons fought the British, Cockpit Country supplies fresh water throughout western Jamaica. Photo: courtesy Jamaica Environmental Trust.

the world, and the relationship between all of us and the planet. I bring that perspective, and then also this approach as a filmmaker, where I am there to record what is happening and what others are trying to communicate. It's not about me, it's about them. 
TF: What kinds of venues screen the films, especially Cockpit Country?

EF: Well, the first one was for a specific reason. It was to stop the mining. Jamaica Environment Trust got money donated. It aired on television, prime time, and the next day the minister had to respond, and that was the end of that. Yes. But it's a struggle. ${ }^{28}$

TF: Alongside your work in Cockpit Country, in Jamaica's interior, you were doing marine conservation work. What did that entail?

EF: Jamaica is one of the most overfished countries in the world, going back to the I940s. It's a crisis for the fishers who are trying to make a living, but also more importantly for the marine environment. It's due to the tourism infrastructure. For example, in Negril they ruined the morass, the wetlands. We've lost 80 percent of our mangroves because tourism is on the shoreline. Building these things destroys the buffer between the marine and the land, which is so important.

TF: How did you get involved in this work?

EF: Through the Nature Conservancy. They were trying to set up a fish sanctuary, a marine conservation area in Pedro Bank, which is our most important fishery. I went out to Pedro and created videos, for instance Massa God Fish Can Done, where we did an exchange between Jamaican fishers and those in Belize. We took them to Belize, where the local communities, many of whom are Garifuna, had self-organized. Their fishing had been on the verge of collapse, but they brought it back to life.

Of course, they have a different situation than us. We're in the middle of the Caribbean and it's not ideal for marine production, so that's part of the reason why we're overfished. We don't have the quality conditions that those along the Central and South American continent have. They have richer marine life to start with. But Belize still had trouble, and they brought it back themselves. Our fishers were able to go and see how they handled overfishing. We took them to one of the marine conservation areas where they went in the water or watched it in a glass-bottom boat, and they were just astounded because they saw fish that no longer exist in Jamaica. They saw the size of the fish. They were amazed, and then when the Belize fishers came to Jamaica and saw the conditions of the fishers in Pedro Bank, and the practices, they were speechless. So this exchange was very, very important.

TF: One of the results was the film? 
EF: Yes, my film Massa God Fish Can Done was screened and/or used for educational purposes throughout the Caribbean, but certainly throughout Jamaica in all the fisher communities who are trying to organize a change of marine fisheries and their practices.

TF: Did Jamaica for Sale come out after that film?

EF: It came out about the same time. It started a little earlier, but it's a more complicated film, so it took longer to finish.

TF: Most of your films are actually quite short, fifteen to thirty minutes.

EF: Right, because they're made for a specific reason, a campaign.

TF: Exactly. They're made for people to see them, readily get a clear message, and apply the information. Jamaica for Sale is much larger in scale. Can you describe how you came to that film and what your motivations were?

EF: When we were shooting the film about Cockpit Country and the bauxite, we were driving to the north coast from Kingston and noticed construction on the shoreline. At that time huge Spanish chains, ones that you could find in Mexico and the Dominican Republic, were coming to Jamaica for the first time. We were the first Anglophone island in the Caribbean getting these very large chains. Spain was investing-so-called investing-in Jamaica when nobody else was. All along that strip that we were driving, we saw these huge resorts beginning to be built.

As you'll see in the film, the issue is beach access in Jamaica. One of the reasons ordinary Jamaicans don't know how to swim, and we don't understand the marine environment, is because we don't have access to the sea, the beach. In 2007 , when I saw all of what was going on, I decided to make that film.

TF: How do you approach filmmaking? Art or craft?

EF: Filmmaking is a craft. Take furniture making. You can only make a chair with the materials you have. It's the same thing with a film. You can have the greatest concept, but you can only make the film with the materials you have. That's why I edit. Editing is the most important thing. So much is done in postproduction. You have all these different pieces and, at some point, for whatever reason-you're out of time, you're out of money-you build with what you have.

The way I shoot is partially constrained by the type of camera I'm shooting with, or the fact that I only use natural light. It's just me. I don't have an 


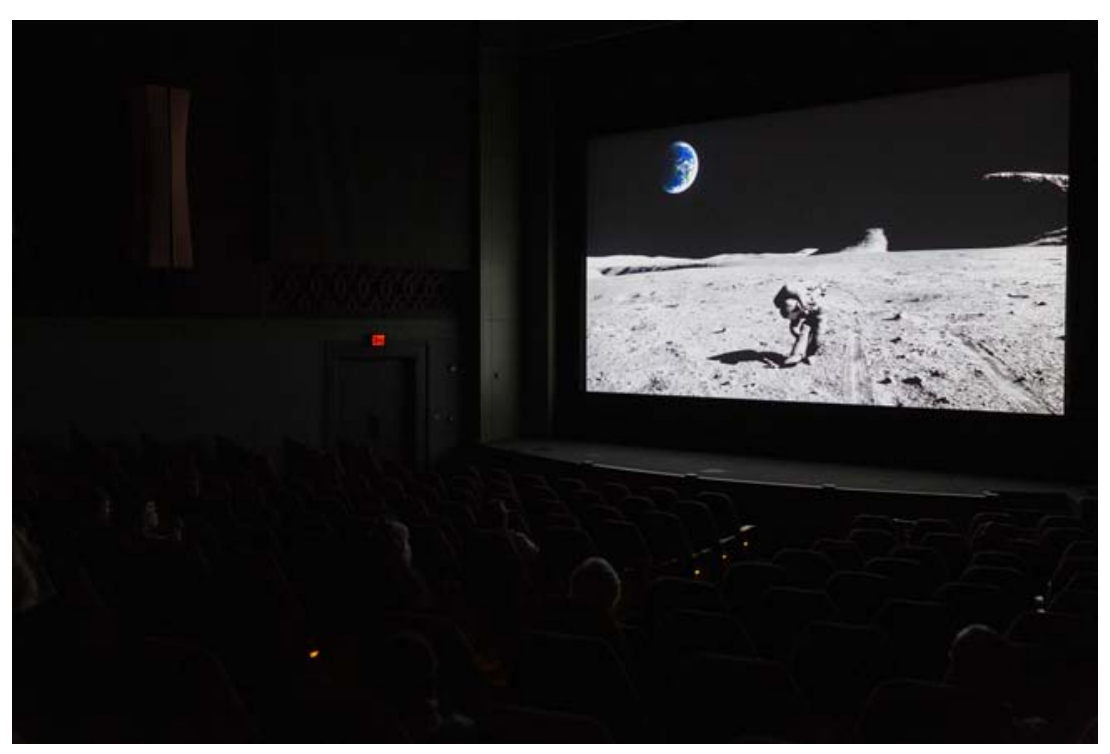

FIGURE 8. Still from Fly Me to the Moon (dir. Esther Figueroa), 2019. Photo: Chaz Mottinger, courtesy Indiana University Communications.

audio person, so maybe I have to get up close. Maybe I'm very, very far away. My camera has an incredibly good lens because I often need to shoot from very far away. Or surreptitiously, right? I need to shoot through fences and things when I can't get in without trespassing. So, yes, I make shooting through the fence an aesthetic trope, but I didn't go in with that plan. It was just the only way I could shoot. I've shot literally hanging out of a car window as we drove by. That's my "tracking shot." I like movement, mobility. But you know, also I need to shoot and run! So again, it's a craft. You have your aesthetic preferences, your preferred formal structures, but it's also based on what's possible.

TF: How is your second feature, Fly Me to the Moon (fig. 8), different from Jamaica for Sale?

EF: I wanted to tell a story in a different aesthetic way. In this case it's more than an hour of archival film compiled from fifty or sixty archives. It's mindboggling.

TF: Wow. How did you approach that and make sense of it?

EF: Well, it's not the editing that's a problem. That's easy. The problem is tracking the stuff down and getting the rights to it. Here's the fabulous thing 
about the internet. I did this film with no money, just me, because I could just pull stuff off the internet. I can't afford to fly to eastern India and shoot the struggle with the Indigenous people. I can't fly to Iceland. I was going to go to Canada, to where Alcan has their smelter, but even that didn't work out. In Fly Me to the Moon, I have this global and temporal rangeEisenhower, Kennedy, Michael Manley, past, present, future-that I'd never be able to afford. But then, do I really want to pay billion-dollar corporations like Disney and GE for footage of people like Muhammad Ali? Hmm? Should Disney get money for an interview with Muhammad Ali? I have a problem with that. I don't know what to do next because I cannot ethically justify the amount of money that I would have to raise to finish this film. I cannot justify it.

TF: The footage you selected situates Jamaica within a much larger story about the environmental impact of the US ambition to venture into outer space.

EF: Because the industry connects, and we are connected. I do what I think is going to be the hardest thing for people to follow. I think the hardest transition is when I go from the struggle in Jamaica to the US moon landing in 1969, which touches on the Vietnam War, Martin Luther King, Stokely Carmichael (Kwame Ture), and Muhammad Ali.

TF: It's not the way we're used to thinking about history, right? You're trying to get us to think about an interconnected history. You're coming from an ecological mindset, thinking about interdependence.

EF: Absolutely.

TF: Let's talk about practice.

EF: I don't know if I have a practice. With the aluminum film-I grew up in Jamaica, right? Bauxite is there (fig. 9). You drive past the so-called mud lake. You drive by the gouges and at the same time you're getting this propaganda from the government that this is a great thing. This industry is moving us forward, it's development, it's modernity. Jamaica for Sale is a critique of development. Part of the critique is to ask, well, what are the options? One is tourism, the other is extraction, mining. But they're both extractive. The whole argument with tourism is that it's jobs. But there's something called leakages. A significant portion of the money that comes from tourism not only doesn't stay in Jamaica, but never even gets to Jamaica. Probably the only thing that doesn't leak are the small wages that people earn. They're claiming there's this money, but most of it doesn't even get to the economy, much less stay in the economy. 


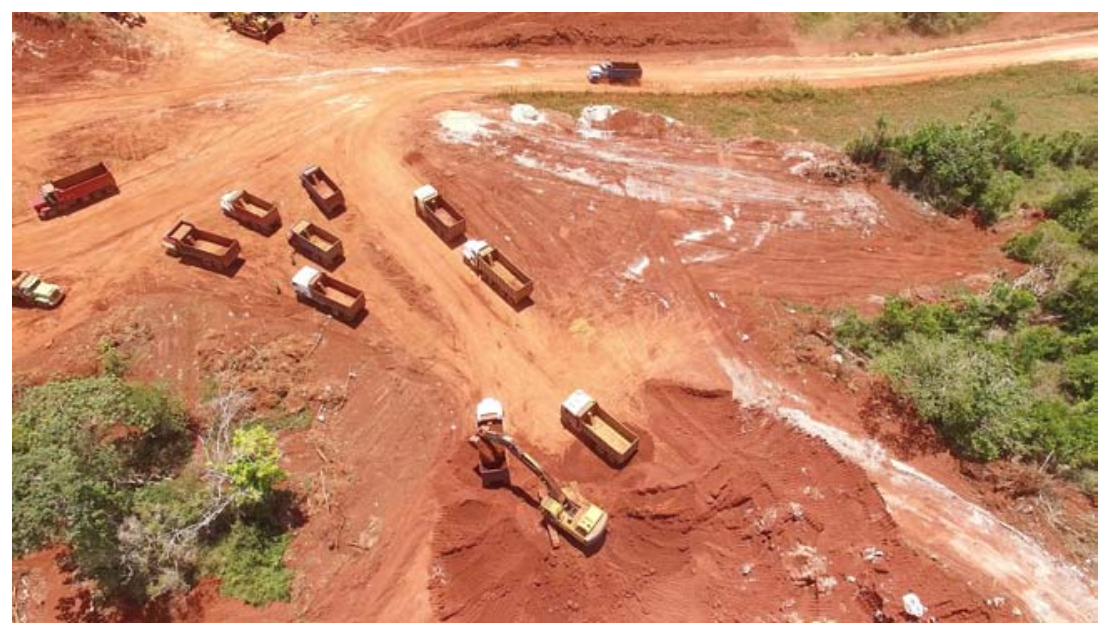

FIGURE 9. Aerial view of bauxite mining trucks. Bauxite is the primary ore of alumina, which is used to make aluminum. Photo: Michael Schwartz, courtesy the filmmaker.

Well, think of the alumina and bauxite industry. Huge multinational corporations weren't even paying taxes. We were getting a shilling, which at the time was about twenty cents, per ton. So, when people look at-I won't say the words, but we know what Donald Trump called certain nations of the world. Even though places like Jamaica and parts of Africa built your wealth. You are rich because of us. Places will not admit that. Britain still will not admit it. They're still sending people back, saying they have no right to be in England. But we saved your ass. We built your ass. One of my favorite lines from the Bob Marley tune says, "If you know your history / then you wouldn't ask me / who the hell do you think I am?" We built you. You could not exist without us. So when you look down at us and think we're pathologically this, that, or the other, we got you to the moon. Your great achievement.

TF: I'm gonna shift gears a little bit. Or no, no, I'm not. I want to continue the same theme.

EF: I didn't really answer you about the process.

TF: Do you want to talk about that?

EF: I've been wanting to make a film about extraction and mining since before Jamaica for Sale. It was always going to be the next feature. An idea sticks around and then I see how things link together and I work on it. It is large, it's huge, it's out of control, and I sit there and I make it make sense in whatever 
way, and that's a singular and very happy thing to do. The unhappy thing is how it lives outside of that, and the money it takes to make it possible.

TF: Do you think of yourself as a Black filmmaker, a woman filmmaker?

EF: No. I think of myself as a feminist filmmaker. The films I make, I make as a woman. I always have a feminist analysis. I always try, depending. I mean, the majority of fishers are male. I can't invent female fishers; they don't exist. But I always have a feminist analysis and I try to have a female voice wherever and predominant when possible. But if I were to submit Fly Me to The Moon to a women's film festival, they'd be like, what is this? Unless it was a festival of women filmmakers who make films about ecology or social justice. You understand what I mean? Because the notion of a woman's film is a film about a woman, or women's things, whatever that means. But the planet! Patriarchy-patriarchy created the violence against the planet, and violence against women is based on this notion that women are less rational, closer to nature, more animalistic. Less like enlightened white males, right? So, yes, I'm a woman filmmaker, but I think of myself as a feminist filmmaker because women's films, typically, are seen in a completely different way.

TF: Can you put into words your feminist analysis? Break down what you mean by that?

EF: I've always been a feminist. From when I was very young, it was clear to me. I grew up with four brothers and an incredibly dominant father. He was the center of the center. It was obvious to me that boys could do whatever the hell they wanted. Freedom of mobility. It is clear to you as a girl growing up what is possible and what is not. What the boundaries are. I, from the youngest of ages, just refused to take on the feminine role. I refused to accept that I couldn't have the mobility, that I couldn't do things, and resolved to be somehow different. At an early age I was reading radical feminist propaganda. As soon as I moved to Puerto Rico, I joined Mujer Intégrate Ahora [Women Integrate Now], created in 1972.

TF: It's hard to imagine you making these films without that analysis, because they do require a physicality. You have to be willing to cross boundaries, hang out of cars. You have to have freedom in your body.

EF: When Heather and I started Juniroa Productions in Hawaii it was the only all-female production company. At the beginning we'd tell the camera guy, our friend, what to do and he'd just ignore us. He would decide he knew better. And we weren't making any money because we had to pay all the technicians. Eventually we figured, ah, I'm doing this myself. So it does take 
a physicality, especially in the beginning when cameras were really heavy. I think that's where my athletic training comes in, because I always have to pace myself. If I know I'm going to be shooting for fourteen hours, I've got to eat well the day before, I've got to hydrate. It's just like training. I've got to rest, recover, the whole thing.

I've been out on shoots in communities where I'm shooting sewage and I'm walking in it. I've got to climb up on something. I gotta do this, that. It's fine. It is about that physicality that you have to claim. I love it all. In Pedro, off the southern coast of Jamaica, we used to go out on the Coast Guard boat and we had to jump off the boat into the sea, into canoes. The physical aspect is part of the excitement. Outdoors or indoors, you have to persevere. It's not about looking pretty, it's not about being glam and talking to some celebrity. That might be fun, but that's not what I'm doing. In Jamaica if I'm on a shoot, I'm almost always the only female, and some man is walking in front of me.

TF: Given the subject of your videos, do you feel optimistic, in a way?

EF: I don't like that word because it's gotten so hackneyed. Hope and optimism have become commercialized and branded, and it's just ridiculous. What I think is-and that's why I called my talk at University of Illinois "Passionate Science: A Utopian Approach to Environmental Activism"you have to have a utopian imagination. You have to have an alternative imagination. Call it what you want. You cannot create actions that are not based on imagination.

TF: What do those of us not living in Jamaica need to know about Jamaica and the environment?

EF: I don't think Jamaica is unique. What's happening in Jamaica has happened elsewhere, and it's continuing to happen.

TF: What are the things-ideas or projects—-that you feel are really urgent?

EF: I think love is urgent. I think ultimately, what matters most in the human sphere is love. Thinking in terms of our place in the universe, decentering the human and emphasizing the planetary and the natural, is urgent. The kind of feminism I grew up in related to this notion of creating alternative imaginations, other ways of being and living in the world, which came from many different forms and sources-identifying with Indigenous ways, or free, utopian collectivity, whatever the hell.

TF: It's about rethinking how things are in a really broad way. 
EF: In every way. It's a combination of who I am and feminism. It frees me up emotionally and energetically because there's a whole bunch of shit that I don't give a shit about, it does not concern me. That frees me from a level of anxiety or social immersion because I am always an outsider. There's nowhere that I am not an outsider, and that frees me from trying to-convince someone of something about me? It's not worth my time.

TF: Could you say more about how you understand the role of imagination and "utopian" thinking in the environmental movement?

EF: Arundhati Roy talks about the need to give space to those who imagine differently. ${ }^{29}$ The fact is, we had a different imagination. The nonaligned movement showed that for a moment there was another option. It didn't have to go to neoliberal global capitalism. There were other ways of being in the world, and it's just a failure of so much that we're in the world we're in rather than some other world. We have this sense of inevitability, but it's not inevitable. That's why a lot of what I show is about how it's not inevitable at any point. It could have been a different story, and it's true in one's life. You turn left one day. You could have turned right, or gone straight, or backed up. You turned left, and then you lived with the consequences. We were taught to accept this natural progression - that there could have been no other than the world we're in. But actually there could have been.

TF: And there still can be?

EF: And there still can be.

TerRI Francis teaches film studies courses and directs the Black Film Center/Archive at Indiana University. She is a scholar of Black film and critical race theory whose work involves archival research, cultural history, and visual analysis, set within the vicissitudes of performance and representation. Francis published her research on Jamaican nontheatrical films as "Sounding the Nation: Martin Rennalls and the Jamaica Film Unit, 1951-1961" in Film History in 2011, and she guest edited a close-up on Afrosurrealism for Black Camera in 2013. Francis is the author of Josephine Baker's Cinematic Prism (Indiana University Press, forthcoming in February 2021), and her essays appear in Transition and Another Gaze. Francis has worked to animate the Black Film Center/Archive as a living, breathing center of new and unexpected ideas about Black film. She has curated the film series "Race Swap," "Black Sun/White Moon," and "Love! I'm in Love!" and the speaker series "Black Film: Nontheatrical" and "Before Representation."

\section{NOTES}

I. Arundhati Roy, "The Trickledown Revolution," Outlook India, September 20, 2010, https://www.outlookindia.com/magazine/story/the-trickledown-revolution/267040.

2. Charles R. Acland and Haidee Wasson, eds., Useful Cinema (Durham, NC: Duke University Press, 20II), 4, 3. 
3. Michael Taylor, "Climate Change in the Caribbean: Learning Lessons from Irma and Maria," The Guardian, October 6, 2017, https://www.theguardian.com/ environment $/ 2017 /$ oct $/ 06 /$ climate-change-in-the-caribbean-learning-lessons-from-irmaand-maria. See also Michael Taylor's presentation recorded by Figueroa, Caribbean Climate Change: The Take Away Messages (2017), https://youtu.be/Gi5y6UmBfFI.

4. For recent discussions of Caribbean film see "Caribbean Cinema as Cross-Border Dialogue" (a close-up edited by Jane Bryce), Black Camera II, no. I (2019): I23-303; "Back and Beyond, the Context," ed. Jean Antoine-Dunne, special issue, Caribbean Quarterly 6I, nos. 2/3 (2015).

5. Rachel Mosley-Wood, "Unbinding Identities: The Challenges to Nationalism's Myths in Jamaica for Sale," sx salon I7 (October 2014): http://smallaxe.net/sxsalon/ discussions/unbinding-identities. See also E. S. Martens, "Independent Documentary Filmmaking in Jamaica: An Interview with Esther Figueroa," Social Identities 19, nos. $3 / 4(2013): 440-53$.

6. Keith Warner, On Location: Cinema and Film in the Anglophone Caribbean (London: Macmillan Education Limited, 2000).

7. See Terri Francis, "Sounding the Nation: Martin Rennalls and the Jamaica Film Unit, 195I-196I," Film History 23, no. 2 (2011): IIO-28. For a book-length study of Jamaican cinema, see Rachel Mosley-Wood, Show Us As We Are: Place, Nation and Identity in Jamaican Film (Kingston: University of the West Indies Press, 2019).

8. Esther Figueroa, "Cockpit Country Still Under Threat from Bauxite Mining," The Gleaner, July 28, 2019, http://jamaica-gleaner.com/article/focus/20190728/estherfigueroa-cockpit-country-still-under-threat-bauxite-mining.

9. Nature documentaries tend to focus on wildlife and specific locations, running the spectrum from reality-based television to educational material, as entertainment or edification. See Gregg Mitman, Reel Nature: America's Romance with Wildlife on Film (Seattle: University of Washington Press, 2009); Cynthia Chris, Watching Wildlife (Minneapolis: University of Minnesota Press, 2006); Derek Bousé, Wildlife Films (Philadelphia: University of Pennsylvania, 2000).

Io. The available videos include Massa God Fish Can Done (2009), https://www. youtube.com/watch?v=woc_DrAUf2A; Cockpit Country Is Our Home (2012), https:// www.youtube.com/watch?v=ylqTfuo 7 PJA; and Cockpit Country: Voices from Jamaica's Heart (2007), https://www.youtube.com/watch?v=x2Psj_UcqQY. Fly Me to the Moon (2019) had a very successful world premiere in Jamaica at the University of the West Indies, Mona, on November 9, 2019, and plans are being made to screen it at universities and community centers. The film won a merit award at the 2019 Awareness Film Festival but has otherwise been rejected by all film festivals entered. Jamaica for Sale (2008/9) won a number of awards at film festivals, including the Audience Award at the Africa World Diaspora Film Festival in 2009, but it is currently only available in DVD format, and there are only a few remaining copies (contact the filmmaker, vagabondmediaı@mac.com). Attempts at digitizing it from the original video master have thus far been unsuccessful, but the hope is to digitize it and make it also available through streaming. 
II. Jhannel Tomlinson and Kevon Rhiney, "Experiential Learning as a Tool for Farmer Engagement and Empowerment in a Changing Regional Climate," Caribbean Quarterly 64, no. I (2018): II 4.

I2. Esther Figueroa, Limbo: A Novel about Jamaica (New York: Arcade, 20I4), I3I.

I3. Deborah Anzinger, "A Piercing Void Where We Meet," Caribbean Quarterly 64, no. I (2018): 5 .

14. Figueroa, Limbo, I3I-32.

I5. Carolyn Cooper, "Emancipate All Beaches Now!"” The Gleaner, July 29, 2018, http://jamaica-gleaner.com/article/commentary/20180729/carolyn-cooper-emancipateall-beaches-now.

16. Rebekah Kebede, "Jamaican Beaches Lure Tourists but Calls to Also Make Locals Welcome," Reuters, May 29, 2017, https://www.reuters.com/article/us-jamaica-landrightsbeaches/jamaican-beaches-lure-tourists-but-calls-to-also-make-locals-welcome-idUSKBNi8 PoSN.

17. Nadia Huggins, July 31, 2019, Facebook post no longer accessible.

18. Jamaican leadership on the environment has been documented in the international press, for example James Ellsmoor, "6 Renewable Energy Entrepreneurs Lighting Up Jamaica," Forbes.com, February 7, 2019, https://www.forbes.com/sites/jamesellsmoor/ 2019/02/07/jamaican-renewable-energy-entrepreneurs/\#422c2c656 4 a; James Ellsmoor, "Make Jamaica Green Again: Io Powerful Women Heading the Sustainability Movement," Forbes.com, February 7, 2019, https://www.forbes.com/sites/jamesells moor/2019/02/07/make-jamaica-green-again-Io-powerful-women-leading-the-sustainabil ity-movement/\#3reed3a636d8. On Jamaica's anti-littering campaign see https:// nuhduttyupjamaica.org/. Also see Jacqueline Charles, "Reusable Bags, Paper Straws, Cardboard Containers: Jamaica Boldly Moves to Save Paradise," Miami Herald, May 30, 2019, https://www.miamiherald.com/news/nation-world/world/americas/haiti/ article230908393.html.

19. Mary Keck, "IU Bloomington Considered One of the Most Beautiful College Campuses in U.S.," News at IU Bloomington, March 29, 2017, https://news.iu.edu/ stories/2017/03/iub/inside/29-iu-bloomington-beautiful-campus.html.

20. The Environmental Protection Agency's website defines superfund sites as areas with known hazardous waste that has been dumped, left out in the open, or otherwise improperly managed, dating as far back as the I930s. There are thousands such contaminated sites all around the United States, fifty-three of which are in the state of Indiana. See https://www.epa.gov/superfund.

2I. See the EPA page on Bennett Stone Quarry, https://cumulis.epa.gov/supercpad/ cursites/csitinfo.cfm?id=0501343, accessed July 31, 2019. For a recent news story on the Sanders Stone Quarry made famous in the film Breaking Away, see George Hale, “'Breaking Away' Quarry Partially Filled In: 'There Would Be 300 People Back There," Indiana Public Media, February 6, 2020, https://indianapublicmedia.org/news/ limestone-company-buries-iconic-quarry-from-breaking-away.php.

22. See the EPA page on Lemon Lane Landfill, https://cumulis.epa.gov/supercpad/ cursites/csitinfo.cfm?id=050I8I2, accessed July 3I, 20I9. For a recent update on the cleanup of Bloomington superfund sites, see Bob Saltzberg, “Bloomington's PCB History: 
Officials Confident In Cleanup But Hesitant To Issue 'All Clear,' Indiana Public Media, January 23, 2020, https://indianapublicmedia.org/news/bloomingtons-pcbhistory-officials-confident-in-cleanup-but-hesitant-to-issue-all-clear.php.

23. See the EPA page on Neal's Landfill, https://cumulis.epa.gov/supercpad/cursites/ csitinfo.cfm?id=0501759, accessed July 31, 2019.

24. For examples of scholarship on environmental racism in the United States see Dorceta Taylor, Toxic Communities: Environmental Racism, Industrial Pollution, and Residential Mobility (New York: New York University Press, 2014). For scholarship on climate change in Jamaica and the Caribbean see Michael A. Taylor, Tannecia S. Stephenson, A. Anthony Chen, and Kimberly A. Stephenson, "Climate Change and the Caribbean: Review and Response," Caribbean Studies 40, no. 2 (2012): 169-200.

25. Derek Walcott was a St. Lucian poet and playwright. He received the 1992 Nobel Prize in Literature.

26. Heather Haunani Giugni is a filmmaker who was instrumental in the establishment of 'Ulu'ulu, the Henry Ku'ualoha Giugni Moving Image Archive at the University of Hawaii - West Oahu. The archive is named after Giugni's father, a longtime aide to the late Senator Daniel K. Inouye. Henry Giugni was sergeant at arms of the Senate from I987 to 1990, the first person of color and Indigenous person to hold such a position. See an episode of Long Story Short with Leslie Wilcox, featuring Giugni, at https://www. pbshawaii.org/long-story-short-with-leslie-wilcox-heather-haunani-giugni/.

27. E Mau Ana Ka Ha'aheo: Enduring Pride is a series of eleven half-hour programs for and about the Native Hawaiian community, including Hawaiian language, history, culture, contemporary issues, music, and dance. For more on this collection see http:// uluulu.hawaii.edu/about and http://uluulu.hawaii.edu/titles/699.

28. As I was editing this interview, a new and troubling development arose around the embattled protection of Cockpit Country, which provides 40 percent of western Jamaica's groundwater. On May 27, 2019, National Wide Radio posted audio clips from Hugh Dixon, executive director of the Southern Trelawny Environmental Agency, in which he comments on a reversal of the November 2017 pronouncement in Parliament that there would be no mining in Cockpit. Noranda Aluminum has announced its plan to mine eight thousand hectares in Cockpit over the next thirty years. Neika Lewis, "Residents Angry after Gov't Reportedly Approves Mining in Sections of Cockpit Country," Nation Wide Radio, May 27, 2019, http://nationwideradiojm.com/residentscry-foul-after-govt-reportedly-approves-mining-in-sections-of-cockpit-country/.

29. See epigraph. 